\title{
Text and History in the War Powers Debate: A Reply to Professor Yoo
}

\author{
Michael D. Ramsey $\dagger$
}

In Textualism and War Powers ("TWP"), I examine the eighteenth-century meanings of "declaring" war, in the hope of shedding some textual light on the long-running debate over the Constitution's allocation of war powers. Previously, that debate appeared to have reached an impasse. Advocates of presidential war power seemed to have the better of the textual arguments, as Congress's power is only to "declare war," which, taken to refer only to the issuance of a formal proclamation of war, did not seem broad enough to cover all power to begin military action. Advocates of congressional war power seemed to have the better of the "Framers' intent" arguments, because the Constitution's drafting and ratifying history, and the political events and commentary of the $1790 \mathrm{~s}$, appeared to assume a leading role for Congress in the decision to commit the nation to war. ${ }^{2}$

TWP argues that close attention to the eighteenth-century meaning of "declaring" war strengthens the textual argument for Congress and weakens the textual argument for the President. First, "declaring" war was used in the eighteenth century to mean not just a formal proclamation, but also an act (typically a hostile attack) that marked the beginning of a state of war. Thus, as John Locke said, one might declare by "Word or Action." This provides a textual basis for reading Congress's war powers broadly. Second, formal proclamations of war in the eighteenth century were seen as a communicative and rhetorical device, not as the prerequisite to the legal state of war (either domestically or internationally). Presidential advocates have suggested that the Declare War Clause gave Congress the power to decide when to invoke the laws of war, though not the power to decide when to use military force, because in the eighteenth century a formal proclamation was prerequisite to the former but not the latter. This gave the presidential side a persuasive affirmative account of the

\footnotetext{
$\dagger$ Professor of Law, University of San Diego Law School.

Michael D. Ramsey, Textualism and War Powers, 69 U Chi L Rev 1543 (2002).

The state of the debate is recounted in id at 1567-69.

3 John Locke, The Second Treatise of Government, in John Locke, Two Treatises of Government 265, \$ 16 at 278 (Cambridge 1988) (Peter Laslett, ed).

4 See John C. Yoo, The Continuation of Politics by Other Means: The Original Understanding of War Powers, 84 Cal L Rev 167, 207-08 (1996).
} 
purpose of the Declare War Clause: Congress has control of the legal aspects of war, but not the military aspects. TWP shows that this is not how the formal proclamations were viewed in the eighteenth century. This leaves presidential advocates with no satisfactory account of what the Declare War Clause was supposed to accomplish, as it makes little sense to accord Congress control over what is essentially a communicative and rhetorical function.

In a wide ranging attack, Professor John Yoo, a longtime advocate of broad presidential war powers, registers his disagreement in quite strong terms. ${ }^{6}$ Professor Yoo brews up quite a methodological tempest, but he lands few blows upon the actual argument of TWP. Indeed, he never seriously confronts either of its central points. He does not deny that influential writers of the eighteenth century, with whom the constitutional generation in America was familiar, spoke of "declaring" war in broad terms that included hostile attacks. He does nothing to undermine TWP's account of the formal proclamation of war as a rhetorical and communicative device. He does not rehabilitate the presidential side's interpretation of the Declare War Clause as addressed to the legal aspects of war, nor provide any new account of the purpose of the Declare War Clause.

Professor Yoo couches many of his objections as methodological, but his critique essentially amounts to the claim that it is not plausible, in light of the Constitution's text, structure, and history, to read the Declare War Clause to encompass declarations by act as well as declarations by proclamation. This, of course, is a point upon which reasonable persons may disagree, and in this Reply I try to show why, despite his objections, the broader interpretation is the better one. However, the more important point, lost in Professor Yoo's overheated methodological rhetoric, is that TWP shifts the burden of proof, as it were, in this debate. Previously, the inability to tie congressional war powers directly to the text of the Constitution, and the plausible explanation of the Declare War Clause as addressed to the legal rather than military aspects of war, offset the historical/Framer's intent arguments for Congress. By showing that the Declare War Clause standing alone is capable of a broad meaning, and that the presidential side has no satisfactory structural account of the clause, TWP makes the arguments from ratification and post-ratification history more decisive. Professor

\footnotetext{
5 See Ramsey, 69 U Chi L Rev at 1587-90 (cited in note 1).

6 See John C. Yoo, War and Constitutional Texts, 69 U Chi L Rev 1639 (2002). For Professor Yoo's previous commentary, see John C. Yoo, Kosovo, War Powers and the Multilateral Future, 148 U Pa L Rev 1673 (2000); John C. Yoo, Clio at War: The Use and Misuse of History in the War Powers Debate, 70 U Colo L Rev 1169 (1999); Yoo, 84 Cal L Rev 167 (cited in note 4).

7 See Yoo, $84 \mathrm{Cal} \mathrm{L} \mathrm{Rev} \mathrm{at} 242$ (cited in note 4) (arguing that the clause's primary function is "to trigger the international laws of war").
} 
Yoo does not acknowledge such a shift in the terms of the debate, but he does nothing to undermine it. ${ }^{8}$

Part I of this Reply shows that Professor Yoo does not seriously challenge the two basic claims of TWP. Specifically, I show that he does not deny that in the eighteenth century declaring war was spoken of in a broad sense to include acts, and that the proclamation of war ("declaring" war in its narrow sense) had primarily a rhetorical and communicative, not legal, function. Part II addresses arguments based on the text, structure, and pre-drafting history of the Constitution. First, in Part II.A, I argue that Professor Yoo does not provide a satisfactory affirmative case for his narrow reading of the Declare War Clause. His reliance on the history of executive power overreads the extent to which that history is determinative; his reliance on the Commander-in-Chief clause is misplaced, as he has not shown that the eighteenth-century commander-in-chief power had anything to do with war initiation; and he has not provided any satisfactory account of why the Constitution would have given the power over formal proclamations-but no other part of war powers-to Congress. Part II.B addresses Professor Yoo's textual and structural objections to the broad reading of declaring war, and finds none of them persuasive. Part III discusses Professor Yoo's arguments based on ratification and post-ratification history. Here I demonstrate that the ratification history does not show what Professor Yoo would like it to show, and that his selective reading of the post-ratification history allows him to ignore many of the founding generation's most important interpretations of the Declare War Clause. Finally, Part IV briefly addresses several substantial mischaracterizations relating to TWP's implications for modern practice.

\section{What PROFESSOR YOO DOES NOT CHALLENGE}

Prior to TWP , the best textual case for presidential war-initiation power rested on two main points: first, that "declaring" war in eighteenth-century terminology referred only to issuing a formal proclamation, and second, that in eighteenth-century practice a formal proclamation, though not necessary to beginning hostilities, was necessary to trigger certain legal consequences under international and domestic law.' These points allowed presidential advocates to argue that the only reading of the Declare War Clause faithful to the constitutional

8 Professor Yoo mischaracterizes TWP as claiming that "the power to declare war must mean something more than what its text suggests." Yoo, 69 U Chi L Rev at 1661 (cited in note 6). As should be clear, nothing in $T W P$ invites the reader to go beyond what the text suggests; the point, rather, is that the text would suggest something more to an eighteenth-century reader than it does to Professor Yoo.

9 See Yoo, 84 Cal L Rev at 204-08, 242-45 (cited note 4). 
text was that Congress had control over the legal aspects of war but not over the initiation of hostilities. TWP's principal mission is to dispute these two points, and Professor Yoo's Response does nothing to undermine TWP's conclusions as to either of them.

\section{A. The Existence of a Broad Definition of "Declaring" War}

$T W P$ 's first central contention is that in eighteenth-century usage "declaring" war could refer to an act that began a state of war, as well as to a formal proclamation. Professor Yoo does not dispute the point. $\mathrm{He}$ quibbles with quotations from Locke and Blackstone, ${ }^{10}$ complains that no attention is given to Montesquieu," and attempts to diminish the importance of quotations from the eighteenth-century writers on the law of nations. ${ }^{12}$ But ultimately he agrees, albeit grudgingly, that TWP "has identified some examples in which some eighteenthcentury writers appeared to use the phrase 'declare war' to mean commence war." ${ }^{13}$

10 Professor Yoo's main point seems to be that Locke and Blackstone did not use the phrase in the context of separation of powers. This is correct, but not surprising, as Locke and Blackstone did not discuss any subdivision of war power, thinking it all properly unified in the executive. Professor Yoo also suggests that the relevant passage from Locke does not say what TWP says it does. This objection is difficult to follow. True, Locke did not use the exact phrase "declare war," but he said that one "declares by Word or Action" and that the result of that declaring is a state of war. See Locke, Second Treatise $\$ 16$ at 278 (cited in note 3). In Locke's terminology, a state of war is created either by formal announcement or by an act signaling intent to go to war, and that both the announcement and the act (not just the announcement) are declarations. This is contrary to prior assumptions, including those in Professor Yoo's work, that declarations could only be made by formal proclamation.

Professor Yoo also objects that Locke was describing the private state of war between individuals in a state of nature, rather than war between nations. While this is correct, he does not explain how it undermines the evidence of Locke's usage. There is no reason to think that Locke would have used different terms in discussing war between nations (which Locke viewed as civilized society's counterpart to war between individuals in a state of nature).

11 Professor Yoo does not argue that Montesquieu said anything directly relevant to the various meanings of declaring war. Professor Yoo's point is broader: that Montesquieu, along with Locke, Blackstone, and others, thought war power belonged (with the rest of the executive power over foreign affairs) to the executive. As discussed in Part II, I agree, but this does not address the question at hand. In Part II, I respond to Professor Yoo's broader point, and explain why I think it plausible that the Framers departed from the teachings of Locke, Montesquieu, and Blackstone in this regard. For present purposes, it is enough to say that Montesquieu did not say anything relevant to the meaning of declaring war.

12 Professor Yoo says that their use of declare, in the sense I have identified, was only "rhetorical." He does not explain what he means by this, and it seems little more than innuendo. All of the passages TWP quotes are descriptive of particular points; there is no reason to think that any of them overstep the bounds of ordinary language. Vattel, for example, said that if a nation takes up arms against another, the nation that is attacked is entitled to view itself as being in a state of war, because the first nation's act of taking up arms "declares" its intent to enter into a state of war. See Ramsey, $69 \mathrm{U}$ Chi L Rev at 1592-93 (cited in note 1). Vattel's statement is not rhetorical, but a description of how the international law of war works.

13 Yoo, 69 U Chi L Rev at 1660 (cited in note 6). 
Unfortunately, Professor Yoo misunderstands what TWP seeks to do with this conclusion, and so works up a good bit of unnecessary indignation. TWP argues that because some writers used "declare" in this way, and these writers were known in eighteenth-century America, the founding generation in America may also have used declare in this way. Of course, it would be a neater argument if we had direct evidence of the Framers adopting one or the other particular meaning of declaring war, ${ }^{14}$ but in the absence of direct evidence we must rely on indirect evidence, and this sort of indirect evidence should not be particularly controversial. Looking at English and international legal treatises of the time, like looking at dictionaries of the time, helps fix a range of possible meanings of the words in question. ${ }^{15}$ It does nothing more, and TWP does not claim otherwise.

The point TWP makes is important, though, because previously the textual argument for presidential war-initiation powers had assumed that the Constitution's Declare War Clause, read literally, could only refer to the issuance of a formal proclamation. TWP shows that this is not true: It might refer only to a formal proclamation (adopting the narrow meaning of declaring war evident in some eighteenthcentury writing) or it might refer to a proclamation or act initiating a state of war (adopting the broad meaning of declaring war also evident in some eighteenth-century writing). Standing alone, the clause is ambiguous. ${ }^{16}$ This is all that TWP draws from the eighteenth-century

14 See, for example, Saikrishna B. Prakash and Michael D. Ramsey, The Executive Power over Foreign Affairs, 111 Yale L J 231, 265-66, 272-73 (2001) (establishing a direct link between treatise writers' use of "executive power" to include foreign affairs power and the Framers' use of the same phrase with that meaning).

15 This very methodology - looking to the influential English and international legal treatise writers to identify possible meanings of constitutional text-was used by Professor Yoo himself in Original Understanding of War Powers. See Yoo, 84 Cal L Rev at 242-44 (cited in note 4). As Professor Yoo stated in that article, the works of international authors "exerted a greater influence on the minds of the Framers than the articles of today's publicists do on today's lawyers. In part, the revolutionary generation relied on English and continental legal authorities due to the disorganized nature of the colonial and early American legal system." Id at 43. Like TWP, Original Understanding of War Powers does not establish any direct link between the treatise writers' use of "declare war" and the founding generation beyond the fact that the founding generation was familiar with the treatises it relies upon.

16 Professor Yoo repeatedly mischaracterizes this part of TWP's argument. He says that TWP finds that "the meaning of the Declare War Clause is so plain that no resort to contextual evidence is necessary." Yoo, $69 \mathrm{U}$ Chi L Rev at 1643 (cited in note 6). This is exactly wrong. The whole point of this part of TWP is that the phrase is ambiguous as to whether it means only a proclamation, or also an act, and that only contextual evidence can answer that question. Professor Yoo also says that TWP ignores contrary evidence and "struggle[s] mightily" to create a false perception of unity in international legal authorities. Id at 1644 . To the contrary, TWP emphasizes the broad range of views held by the treatise writers on the subject of declaring war, and carefully points out that important legal authorities of the time also used declaring war in its narrower sense to refer only to a proclamation. He further says that the "core" of $T W P$ 's argument is that because "formal declarations of war served no real purpose under international law" the treatise writers' “rhetorical use of the phrase 'declaring war' ... must have been meant to give 
treatises' use of declaring war. ${ }^{17}$

Because Professor Yoo misunderstands this point, he thinks TWP claims quite a bit more for the eighteenth-century treatises. Specifically, he sees $T W P$ as arguing that because some eighteenth-century treatise writers sometimes spoke of declaring war to include acts, the Framers must have used it in this way. If that were TWP's claim, then Professor Yoo would be justified in complaining of a "myopic" ${ }^{\text {"1, }}$ focus on the treatise writers at the expense of the many other historical influences on the Framers. But this is not TWP's argument. The argument is that because some eighteenth-century authorities used "declare" broadly, the Framers also might have used "declare" broadlyand Professor Yoo does not say anything to undermine that conclusion.

\section{B. The Meaning of the Formal Proclamation}

TWP's second central contention is that the eighteenth-century proclamation of war was primarily a communicative and rhetorical device, and was not necessary to trigger a legal state of war. In his Response, Professor Yoo does not provide a clear account of his view of the proclamation's role, but for the most part he seems to accept $T W P$ 's description, and in any event says nothing to undermine it.

First, Professor Yoo spends much time disparaging the authorities on which TWP relies, without directly challenging TWP's conclusions in this regard. His objections are both unhelpful and misplaced. For example, TWP relies on English treatise writer Matthew Hale, whose works contain a clear description of the law of war in practice, and a clear rejection of the idea (associated with Grotius and relied on by Professor Yoo) that a formal proclamation of war was prerequisite to invoking the laws of war. ${ }^{19}$ Professor Yoo objects that Hale was not an influential authority for the founding generation, ${ }^{20}$ but that is surely incorrect. Intellectual historian Bernard Bailyn writes that "the great

Congress the power to commence hostilities." Id at 1641. Again his description of TWP is quite muddled. The core of $T W P$ 's argument is that the treatise writers used "declaring" war in $t w o$ different ways: to refer only to a formal proclamation, and to refer to an act that signaled the beginning of a state of war (by proclamation or by attack).

17 Professor Yoo also does not appear to dispute TWP's use of dictionary evidence. As discussed, the dictionary definition of "declare" included the idea of making plain or showing in open view. Ramsey, $69 \mathrm{U}$ Chi L Rev at 1590 (cited in note 1). Applied to war, it is ambiguous whether this definition would cover acts, as well as proclamations, that showed the existence of a state of war. Professor Yoo cites some additional dictionaries to the same effect, but does not show anything to resolve the ambiguity. See Yoo, $69 \mathrm{U}$ Chi L Rev at 1669-70 (cited in note 6).

18 Yoo, $69 \mathrm{U}$ Chi L Rev at 1646 (cited in note 6).

19 See Ramsey, 69 U Chi L Rev at 1574-75 (cited in note 1).

20 See Yoo, 69 U Chi L Rev at 1644 (cited in note 6). 
figures of England's legal history, especially the seventeenth-century common lawyers, were referred to repeatedly" in revolutionary America, and adds that of these "Hale was a particularly well-known and attractive figure." ${ }^{21}$ More importantly, Professor Yoo never says that Hale was wrong, and there is every indication that Hale was right about the state of the law. And whether or not the Framers were familiar with Hale, presumably they were familiar with the actual state of the law (which is what Hale was recounting). ${ }^{2}$

Indeed, through much of his Response Professor Yoo emphasizes the proclamation's role as a means of notification, which is precisely consistent with the way TWP views it. ${ }^{23}$ Professor Yoo does claim to dispute TWP's view of the proclamation, but only by mischaracterizing it. According to Professor Yoo, TWP says that in the eighteenth century the proclamation "served no real purpose." $T W P$ says no such thing. To the contrary, TWP shows that proclamations continued to be used in the eighteenth century for a variety of communicative purposes. They were useful to let other nations (and one's own citizens) know of an outbreak of hostilities-no small matter in a world before mass communications technology. They were a useful rhetorical device to explain to third parties, skeptical subjects, and perhaps even the opposing side the causes and goals of the war. They might be used to publicize certain edicts that would be in force as a consequence of the war, or they might be used to announce that the war was intended to be limited in scope or effect. They might be used to bring a certain sovereign gravity to the war-an unannounced set of skirmishes, while no less a war, might not be undertaken with the same

21 Bernard Bailyn, The Ideological Origins of the American Revolution 30 \& $\mathrm{n} 11$ (Cambridge 1967). Professor Yoo elsewhere relies on Bailyn as an important source of the founders' thought. See Yoo, 84 Cal L Rev at 197-99 (cited in note 4). Professor Yoo elsewhere mentions Jean Jacques Burlamaqui as a leading influential author, yet he now disparages him as obscure. Compare Yoo, 84 Cal L Rev at 243 n 366 (cited in note 4), with Yoo, 69 U Chi L Rev at 1646 n 14 (cited in note 6). See generally Ray Harvey, Jean Jacques Burlamaqui, A Liberal Tradition in American Constitutionalism (North Carolina 1937) (discussing the influence of international writers such as Burlamaqui).

22 Professor Yoo complains that I think Hale's comments on war are as important as James Madison's. See Yoo $69 \mathrm{U}$ Chi L Rev at 1644 (cited in note 6). Of course, whenever Madison said anything about war power, he advanced a vision precisely opposite to Professor Yoo's (a point Professor Yoo does not mention). The relevance of Hale, though, is (as Professor Yoo seems determined to misunderstand) that Hale explained as a legal and practical matter how a state of war began and what it meant. In this sense Hale's work acts like a legal dictionary, defining and explaining terms that the Framers used (but did not always fully explain). This does not mean Hale is more or less important than Madison-he is important for a different reason.

23 Yoo, 69 Chi L Rev at 1669-73 (cited in note 6) (discussing "The Meaning of Declare"). On the other hand, when it suits his purpose, Professor Yoo slips back into describing the proclamation as prerequisite to something (though it is never clear what). See id at 1652 \& n 38 (discussing Blackstone).

24 Id at 1641. 
degree of seriousness by the combatants as one stated formally. And, as Professor Yoo says, they could (at least in theory) be used to show sovereign endorsement of military action, but they were not the only (or even the primary) means of making that showing. TWP's point is not that proclamations were not useful, but that they were not necessary. They were a convenience, adopted at times when they coincided with strategic goals, and ignored when they did not. ${ }^{25}$ Most of what Professor Yoo says about proclamations in his Response is consistent with this view.

Relatedly, Professor Yoo does nothing to rehabilitate the idea, associated with Grotius, that a proclamation was necessary in international law to invoke the laws of war (that is, to legalize what otherwise would be murder and piracy). As TWP shows, the laws of war applied to wars that existed in fact, whether or not there had been a formal proclamation. True, a proclamation could invoke a legal state of war if none previously existed, and it could be evidence of sovereign approval of hostilities (a necessary condition for invoking the laws of war) if sovereign approval was in doubt; but in wars begun by sovereign-authorized hostilities rather than formal proclamations it was the hostilities and not the proclamation that inaugurated the legal state of war. ${ }^{26}$ By the time of the framing, Grotius's ideas of 150 years earlier had been decisively rejected in theory and practice, and Professor Yoo provides no reason for thinking otherwise. In particular, it was widely recognized that the use of formal proclamations, especially in advance of hostilities, was falling into disuse in the eighteenth century, and yet Professor Yoo gives no examples of the absence of a proclamation being determinative of a war's legal status. ${ }^{27}$

Third, apparently recognizing the dearth of authority for his earlier view of international law, Professor Yoo in his Response falls back on the claim that the proclamation of war was necessary to accomplish certain domestic legal effects. Thus he suggests that the government's constitutional powers are greater when war is formally proclaimed than when it is not. But he cites no credible authority for such a proposition, and I am not aware of any. ${ }^{28}$ It may well be that the gov-

25 See Ramsey, 69 U Chi L Rev at 1586-87 (cited in note 1). This is basically how Professor Yoo describes the formal declaration in at least parts of his Response. See Yoo, $69 \mathrm{U}$ Chi L Rev at 1649 (cited in note 6).

26 This argument must be distinguished from the argument in the previous Part, which asserted that the usage of declaring war was ambiguous. Here, I think we can say with confidence that the state of international law was not ambiguous.

27 In particular, the Framers would have been aware that in the two major wars fought between Britain and France in America without prior proclamation - the Seven Years' War and the American Revolution - the combatants did not treat each other as pirates.

28 The closest Professor Yoo comes to authority is the Korematsu case. See Korematsu v United States, 323 US 214 (1944). Aside from the dubious validity of that holding, it is unpersua- 
ernment's constitutional powers are greater when the nation is in a state of war than when it is not, but the augmentation turns upon the war itself, not upon the proclamation. ${ }^{29}$

Fourth, Professor Yoo appears to have retreated from an earlier suggestion that the eighteenth-century proclamation had legal consequences because it provided a distinction between "total war" (or "full-scale war") and limited hostilities. ${ }^{30}$ This idea was never fully developed in his earlier work, and TWP argues that it also has no basis in eighteenth-century international law or practice. While people in the eighteenth century did sometimes speak of "perfect" and "imperfect" wars (which may roughly correspond with what we describe as total and limited war), the term was descriptive rather than legal. Professor Yoo does not discuss this issue in his Response.

As a result, there is little if anything left of the idea of a proclamation as a necessary legal act. Although Professor Yoo sometimes continues loosely to describe the proclamation as necessary to trigger a changed legal state, when he actually describes it in detail in his Response he adopts a view essentially the same as that expressed in $T W P$ : that it was largely a rhetorical and communicative device. ${ }^{31}$

This conclusion is important because it deprives the presidential side of its best explanation of the Declare War Clause. As I shall explain in the next Part, Professor Yoo also does not contest that the Declare War Clause serves to transfer the power of declaring war (whatever that means) from the President to Congress. The question, of course, is whether the power transferred is the power over proclamation and action (the broad meaning of "declare") or only the power over proclamation (the narrow meaning of "declare"). So long as

sive first because that case, decided 150 years after the founding, is not indicative of the original understanding, and second because it does not even stand for the proposition Professor Yoo asserts. In Korematsu, the Court said the government's powers of selective internment were enhanced by the state of war, but did not rely upon the existence of a formal proclamation. See id at 220 ("[W] hen under conditions of modern warfare our shores are threatened by hostile forces, the power to protect must be commensurate with the threatened danger.").

Professor Yoo also relies on some modern statutes that make certain presidential powers depend upon the existence of a formal proclamation. Obviously, the fact that some Congresses in the twentieth century chose to make some grants of power turn on a formal declaration says little about what a formal declaration meant, as a constitutional matter, in the eighteenth century.

29 The exceptions to the Third Amendment's ban on quartering troops, for example, turn upon the existence of a state of war, not upon the existence of a formal proclamation. See US Const Amend III.

30 See Yoo, $84 \mathrm{Cal} \mathrm{L} \mathrm{Rev} \mathrm{at} 268$ (cited in note 4).

31 To be sure, a proclamation could be a triggering legal event, if it were issued before the beginning of hostilities, since at that point the proclamation, and not the hostilities, would begin the war. But as Professor Yoo himself has shown, proclamations were rarely used this way. Proclamations might also clarify that a war had begun when the hostilities were conducted at a low and inconclusive level. But this is an example of their communicative use, not evidence that they were legally prerequisite to anything. 
presidential advocates such as Professor Yoo could associate the power over proclamation with the power over the legal aspects of war (by saying that the proclamation was necessary to trigger a certain legal status), they could tell a plausible story about the structural function of the clause, read narrowly. That is, they could say that the clause transferred control of the legal aspects of war to Congress (which as the lawmaking body might be seen as a logical locus of such power) while leaving the executive aspects of war initiation to the President. But if the power over proclamation is only rhetorical and communicative-not "useless" but also not necessary to any particular legal status - then it becomes hard to explain why this power would be singled out for transfer from the President to Congress. As explained in $T W P$, the structural puzzle created by the narrow meaning of "declaring" war becomes an important reason for preferring the broad meaning of that phrase.

\section{Challenges BASEd on TeXt, Structure, AND PRE-DRAFTING HISTORY}

For all of the scorn Professor Yoo directs to TWP, he apparently agrees with the way TWP frames the question: Which of the two eighteenth-century meanings of "declaring" war best fits with the way the phrase is used in the Constitution? Professor Yoo's argument boils down to the claim that it is more plausible to read the Declare War Clause narrowly to refer only to a proclamation of war, rather than broadly to include an act triggering a state of war as well as a proclamation (even though both are possible eighteenth-century meanings). This Part considers his arguments based on the text and structure and pre-drafting history of the Constitution, while the next addresses his arguments based on ratification and post-ratification history.

\section{A. The Case for the Narrow Meaning of the Declare War Clause}

Professor Yoo begins by saying that he will use his Response to build a "comprehensive textual and structural defense" of presidential war powers. ${ }^{32}$ Unfortunately he becomes so bogged down in carping about TWP's methodology that he fails to deliver on this important enterprise. Rather, his argument is devoted almost entirely to repeating his prior historical arguments about the meaning of executive power, rather than giving a structural account of the Declare War Clause itself. This might be enough if one believed that the Declare War Clause had a single meaning that encompassed only formal proclamations, and thus could not convey an exclusive power over war- 
initiation to Congress; but if one agrees that TWP establishes a possible alternative meaning that includes acts as well as proclamations, Professor Yoo's approach no longer seems sufficient.

1. Executive power and the "currents of history."

Professor Yoo takes TWP severely to task for "ignoring" the Executive Power Clause of Article II, Section 1 of the Constitution, and the eighteenth-century understanding of war power as a part of the traditional executive power over foreign affairs. ${ }^{33}$ Apparently his argument is that if one studies the historical background of executive war-initiation power, one will see that (in his phrase) the "currents of history" lead inexorably to the idea of presidential war-initiation power. Thus (he says) we need not spend too much time on the eighteenth-century meanings of declaring war, since in any event it is inconceivable that the Framers would have assigned war-initiation power to Congress.

This is deeply flawed, both as a methodological critique and as a substantive argument. As to methodology, the charge against TWP is odd, because TWP prominently identifies the Executive Power Clause as the most important source of presidential foreign affairs power, and as the centerpiece of the case for presidential war powers. As TWP explains, the constitutional generation understood executive power to encompass the great foreign affairs powers of the English monarch (including war powers), although they also understood those powers to be limited by the Constitution's grants of foreign affairs power to other branches. ${ }^{34}$ The question is whether the Declare War Clause limits the formerly executive power of war initiation.

Professor Yoo may believe that TWP "ignores" the Founders' thinking about executive power because it presents the foregoing conclusions in summary form, without surveying the complex historical and intellectual currents that underlie them. But TWP does not stand alone. It builds upon my prior extensive work, with my colleague Saikrishna Prakash, published in the Yale Law Journal as The Executive Power over Foreign Affairs. ${ }^{35}$ That article shows how the history of executive power leads to the conclusions TWP takes as a starting point. In particular it emphasizes how the English conception of executive power, especially as recounted by the great political commentators such as Locke, Montesquieu, and Blackstone, influenced the founding generation's vision of foreign affairs power. ${ }^{36} T W P$ also

\footnotetext{
33 See id at 1644.

34 See Ramsey, 69 U Chi L Rev at 1561 (cited in note 1).

35 Prakash and Ramsey, 111 Yale L J 231 (cited in note 14).

36 See id at 265-87.
} 
builds upon Professor Yoo's own work in the California Law Review, The Original Understanding of War Powers, which reviews the Framers' experiences with executive war power, and describes the evolution of the Framers' thinking at Philadelphia about executive power and their embrace of a unitary and energetic chief executive, subject to the funding constraints of Congress.

Although TWP has little quarrel with the historical account in The Original Understanding of War Powers, ${ }^{38}$ The Executive Power over Foreign Affairs also sounds a countervailing theme. The Founders were not comfortable with the full extent of executive foreign affairs powers reflected in the English model, so they did what Locke, Montesquieu, and Blackstone would never have countenanced: They divided the formerly unified powers of the foreign affairs executive by assigning some traditionally executive powers, in whole or part, to other branches. ${ }^{39}$ The most familiar of these, of course, is treatymaking power, formerly an entirely executive function that under the Constitution became partly a senatorial prerogative. ${ }^{40}$ As The Executive Power over Foreign Affairs points out, the Constitution contains a range of such allocations, each of which was understood to be a qualification of what otherwise would have been executive/presidential power, pure and simple. In this way the article crafts what it calls the "residual principle": The President, by virtue of the executive power, has all the traditional executive foreign affairs powers of the English system, except those specifically allocated elsewhere by the Constitution. But-and it is an important "but" - the corollary of this principle is that the foreign affairs powers given to another branch by the Con-

37 See Yoo, 84 Cal L Rev at 256-69 (cited in note 4).

38 That is, I have no quarrel with Professor Yoo's account, in Original Understanding of War Power, of the evolution and practice of war power under the English constitution, with the founding generation's experiences with war powers, or (for the most part) with the extent to which the English experience influenced the founding generation. As should be clear from the previous section, I think Original Understanding of War Power gives an incomplete account of declaring war under eighteenth-century international law. I also think it overstates the degree to which the founding generation relied on the English experience to the exclusion of other influences, as the Framers were also influenced by classical history and by the attempts at federation in their more immediate past, including Germany and the Netherlands. But my principal objection is not with Professor Yoo's history, but the conclusions he appears to draw from it in War and Constitutional Text. See Yoo, $69 \mathrm{U}$ Chi L Rev at 1654 (cited in note 6).

39 In contrast, Locke, Montesquieu, and Blackstone emphasized the importance of unified foreign affairs powers in the chief executive. Locke, for example, said that separation of foreign affairs power and executive power would invite "disorder and ruine." Locke, Second Treatise $\S 148$ at 366 (cited in note 3). See Prakash and Ramsey, 111 Yale L J at 286 (cited in note 14) ("[B]y splintering the executive power of foreign affairs across three entities, the delegates had rejected the wisdom of Locke and Montesquieu.").

40 See US Const Art II, $\$ 2, \mathrm{cl} 2$.

41 See Prakash and Ramsey, 111 Yale L J at 280 (cited in note 14) (stating that the delegates to the Constitutional Convention "divided up executive power with an eye to ensuring that no one entity would dominate foreign affairs"). 
stitution are taken away from the President, even though they were previously part of the traditional executive power. ${ }^{42}$

For all Professor Yoo complains about TWP ignoring the historical context of the Constitution's Executive Power Clause, he does not appear to contest the conclusions of The Executive Power over Foreign Affairs. He too sees the Executive Power Clause as the centerpiece of presidential foreign affairs authority. ${ }^{43}$ Moreover, he apparently agrees with the residual principle of executive power identified in The Executive Power over Foreign Affairs. In particular, Professor Yoo agrees that the President cannot issue a formal declaration of war (which is the power he thinks resides in the Declare War Clause) even though that was part of the traditional executive power in foreign affairs. ${ }^{45}$ Thus he and I agree that the effect of the Declare War Clause is to reassign a formerly executive power to Congress; it remains to ask how broad the declare-war power is. These observations are important, though, to refute two hotly pressed but entirely unfounded charges made by Professor Yoo in his comments: that TWP treats the Declare War Clause in isolation, and that it ignores the historical and intellectual context of executive power. As should be clear, TWP works within the extensive context of executive power described in The Executive Power over Foreign Affairs and The Original Understanding of War Powers. ${ }^{4}$

As to the substance, there is quite a bit less than meets the eye to Professor Yoo's complaints about "ignored" constitutional background. Professor Yoo writes as if there were some "smoking gun" in the pre-1787 backdrop to the Constitution that renders the idea of reduced executive war powers implausible. Thus he says, without offering any specifics, that TWP is "out of step" with the evolution of constitutional thought in pre-Convention America, and (more colorfully) that it "swims against the currents of history.", Professor Yoo never says what it is about the Constitution's historical backdrop that makes TWP implausible, and in fact there is nothing.

The truth is that the historical context of the Constitution, while necessary to set the stage for a discussion of war powers, does not it-

42 See id at $252-55$.

43 See Yoo, $69 \mathrm{U}$ Chi L Rev at 1662 (cited in note 6).

44 See id.

45 See Yoo, 84 Cal L Rev at 255 (cited in note 4) (agreeing that the Constitution "transfer[red] the power to declare war from the executive to the legislature").

46 I should be clear that I do not regard the conclusions of TWP as compelled, or even foreshadowed, by The Executive Power over Foreign Affairs. That article aids in framing the question TWP asks, but it does not answer it. In particular, the views expressed in TWP are my own, and do not necessarily represent the views of my Executive Power co-author, Professor Prakash.

47 Yoo, 69 U Chi L Rev at 1647 (cited in note 6). 
self provide any final answers. To the contrary, at least three historical trends stand directly counter to Professor Yoo's idea that the Framers inevitably chose broad presidential war-initiation powers. First, while it is true that the founding generation in America was influenced to some extent by the ideas of Montesquieu and others concerning executive power, and by their practical experience under the English system, the founding generation did not accept a unified executive power in foreign affairs. Among other matters, the Constitution rejects sole executive control over treatymaking, diplomatic appointments, and granting letters of marque and reprisal. All of these functions were part of the executive's foreign affairs power in Montesquieu's theory and in English practice, yet the Constitution assigns them in whole or part to other branches of government. Thus the Framers were quite capable of rejecting Montesquieu, and watering down the executive foreign affairs power, when they wished. If the Framers were willing to limit the executive's historical treatymaking power (as they assuredly did), surely they were at least as capable of limiting the executive's historical warmaking power.

Second, in the specific context of war powers, we know that many of the leading Framers did not accept the idea of war-initiation power as a presidential power. Indeed, the Convention came close to stripping away all of the executive's major war powers. As recounted in The Executive Power over Foreign Affairs, in the initial "Virginia draft" of the Constitution offered by Edmund Randolph at the beginning of the Convention, it was proposed to give to the national executive the "[e]xecutive rights vested in the Congress by the Confederation." ${ }^{48}$ This drew heavy criticism from some delegates on the ground that it would give the executive the "power of war and peace." objections lead to the whole idea of "executive power" being withdrawn for the time being. When the Convention (through its Committee of Detail) later produced a draft restoring a general grant of "executive power" to the President, it included a clause giving Congress the power to "make war". Only when this clause was brought to the

48 Max Farrand, ed, 1 Records of the Federal Convention of 178721 (Yale 1937). The historical background is recounted in greater detail in Prakash and Ramsey, 111 Yale L J at 279-87 (cited in note 14).

49 Farrand, 1 Records at 65-70 (cited in note 48). See also Prakash and Ramsey, 111 Yale L $\mathrm{J}$ at 281-82 (cited in note 14). Significantly, one of the chief objectors was Madison, who said that "executive powers ... do not include the rights of war and peace," and successfully moved to strike the grant of executive power. Id at 282.

50 Max Farrand, ed, 2 Records of the Federal Convention of 1787182 (Yale 1937). See also Prakash and Ramsey, 111 Yale L J at 284-85 (cited in note 14). This formulation, as Professor Yoo agrees in a different context, appears to come from Montesquieu's formulation of the executive's war power. See Yoo, 69 U Chi L Rev at 1653 (cited in note 6). The Committee of Detail plan contained other substantial limitations on traditional executive power in foreign affairs, including total Senate control over treatymaking and ambassadorial appointments. As a result, in 
Convention as a whole was the phrase "declare" substituted for "make," thereby preserving at least some war powers to the President. ${ }^{\text {s1 }}$ Moreover, in the course of the debate many Convention delegates specifically stated that the President should not have substantial powers over the decision to go to war. ${ }^{\text {s2 }}$ In short, it cannot be that history inevitably drove the Framers to embrace presidential warinitiation powers, since a substantial number of them strongly opposed such an allocation.

Third, the English model of war powers was not the only historical example valued by the Framers. In addition to the English experience, an important influence was classical history, in which most educated Americans of the eighteenth-century were well versed. ${ }^{\text {s4 }}$ In particular, educated Americans were familiar with, and influenced by, the classical accounts of the Roman Republic, which was one of history's most striking examples of successful (albeit imperfect) republican government, and which developed an important early version of separation of powers. ${ }^{\text {ss }}$ In the Roman system the consuls (co-chief magis-

the words of The Executive Power over Foreign Affairs, the committee presented a "defanged" executive power that proved acceptable to the once-skeptical Convention. Prakash and Ramsey, 111 Yale $\mathrm{L} J$ at 284 (cited in note 14).

51 Farrand, 2 Records, at 318-19 (cited in note 50). Madison, who had objected to complete executive power over war and peace, was the one who ultimately made the motion to restore some of the war power to the President. See id.

52 I count at least eight delegates making such comments: Farrand, 1 Records at 64-65 (cited in note 48) (Pinckney); id at 65 (Rutledge); id at 65-66 (Vilson); id at 70 (Madison); id at 292 (Hamilton); Farrand, 2 Records at 318 (cited in note 50) (Sherman and Gerry); id at 319 (Mason). At least two others heavily implied that the President should not have substantial war powers. See id at 319 (Ellsworth and King).

53 Thus Professor Yoo is only partially correct in saying that I do not rely heavily on the records of the Convention in reading the Declare War Clause. I agree with some of the reasons Professor Yoo and others have advanced against using the records incautiously to answer specific questions about the meaning of constitutional text. But the drafting history surely shows without ambiguity that the Convention had reservations about Montesquieu's unified executive power in foreign affairs as a whole and Montesquieu's unified executive war powers in particular.

54 See Bailyn, Ideological Origins at 23-24 (cited in note 21) ("Most conspicuous in the writings of the Revolutionary period was the heritage of classical antiquity. Knowledge of classical authors was universal among colonists with any degree of education, and references to them and their works abound in the literature."). See generally Richard Gummere, The American Colonial Mind and the Classical Tradition (Cambridge 1963).

\section{See Neal Wood, Cicero's Social and Political Thought 159 (California 1988):}

The doctrine of the mixed constitution is one of the most important legacies of ancient political theory to modern times. Not only did it have a decisive impact on the general development of the idea of constitutionalism since the Middle Ages, but also, in the early modern period, especially on the theory of mixed monarchy, the English Classical Republicans, and on Montesquieu and the American founding fathers, who devised and instituted the notion of the separation of powers. Basic to that notion is the historical interpretation of the Roman constitution as a mixture, expounded by Polybius, Cicero, and other writers.

See also John Adams, 1 A Defence of the Constitutions of Government of the United States of 
trates elected for one-year terms), the Senate (an aristocratic assembly), and the Populus Romanus (the popular assembly) are recognizable as distant ancestors of the Constitution's President, Senate, and House of Representatives, although of course both the theory and practice of the Roman bodies differed substantially. For present purposes, it is significant that the consuls had command of the military, but the decision to initiate war (other than defensively) required the assent of both the Senate and the popular assembly (together forming the legislative body)..$^{36}$ As John Adams noted in his comprehensive 1787 survey of ancient constitutions, in Rome the people "determine concerning peace and war." ${ }^{\text {,57 }}$ In short, Roman war-initiation power was (at least in theory) a legislative power. The Roman Republic thus was a competing model to the English system, and the Framers would have been well aware of both versions of war power. Professor Yoo's suggestion that they inevitably chose the English system is simply unfounded.

None of the foregoing proves that the Framers assigned warinitiation powers to Congress through the Declare War Clause. What is clear, however, is that the historical background of executive power, and of the Constitution as a whole, does not bear the weight Professor Yoo places upon it. The idea of presidential war-initiation power and the idea of congressional war-initiation power are both plausible results of the Framers' intellectual and practical backgrounds. Attempts to draw out any more conclusive lessons of history will inevitably fall victim to the bias of selective emphasis. One might emphasize the

America 216 (De Capo 1971) (describing the Roman system as "a mixture of monarchy, aristocracy, and democracy, extolled by Polybius .... As the constitutions of Rome and Sparta lasted so many centuries longer than others of Greece and Italy, and produced effects so amazing upon the human character, we may rationally ascribe that duration, and those effects, to this composition."); id at 170-71 (describing the Roman system of mixed government). For the purest ideal statement of the Roman system of separation of powers, see Polybius, 6 The Histories 309-11 (Cambridge 1960) (W.R. Paton, trans).

56 See Wolfgang Kunkel, An Introduction to Roman Legal and Constitutional History 9 (Oxford 2d ed 1973) (J.M. Kelly, trans) ("The body of citizens which gave the state its name [Populus Romanus] was also, in the Republic at least, its supreme political organ. In its assembly (comitia, from com-ire, to come together) decisions were taken on war and peace, magistrates were chosen, and statutes passed"); Polybius, 6 Histories at 303 (cited in note 55) ("[A]nd what is most important of all, they [the people] deliberate on the question of war and peace."). Another of the classical historians, Livy, gives at least two prominent examples of the popular assembly debating initiation of war. See Titus Livius, 1 The History of Rome 403 (Bangs, Brother, \& Co. 1855) (George Baker, trans) (initiation of Second Punic War against Carthage); Titus Livius, 2 The History of Rome 95 (Bangs, Brother, \& Co. 1855) (George Baker, trans) (initiation of war with Philip of Macedon).

57 Adams, 1 Defence of the Constitutions of the United States at 173 (cited in note 55). This is not to say, of course, that Roman practice always followed the theory. See generally Arthur Eckstein, Senate and General: Individual Decisionmaking and Roman Foreign Relations, 264-194 $B C$ (California 1987) (suggesting that the consuls exercised considerable discretion in practice while commanding the military in the field). 
founders' desire to reinvent the energetic foreign affairs executive of the English system, subject primarily to the procedural constraints of funding and impeachment, and conclude that war powers must lie with the President. Or one might emphasize the founders' desire to establish more specific legislative participation in particular foreign affairs decisions (as was done, for example, with treaties) and conclude that war powers must lie with Congress. But neither view is a complete account, because both themes are important and undeniable parts of the founding. Professor Yoo to the contrary, the "currents of history" do not all flow in the same direction, sweeping inexorably to his conclusion. History does not work that way; we cannot judge from history alone what the Framers must have done, but can only attempt to unlock the meaning of the words of their final product, taking into account the swirling historical currents in which it was written. ${ }^{\text {s. }}$

Thus, despite Professor Yoo's self-appointed status as a guardian of the proper uses of history in legal interpretation, it is he (and not $T W P$ ) who misuses the historical context. His executive power argument, as pressed in his Response, is not really a textual argument, but an argument of historical inevitability. Professor Yoo essentially claims that, whatever the Declare War Clause could mean, history shows that the Framers must have endowed the President with war-initiation powers, based on their understanding of the English practice and their reliance upon the English model of executive power as interpreted by commentators such as Locke, Blackstone, and Montesquieu. Because these thinkers saw war-initiation powers as executive powers, checked not by the participation of the legislature in the actual decision to go to war, but by the legislature's control over the funding that is neces-

58 Professor Yoo is particularly scomful of TWP's supposed lack of attention to the works of leading intellectual historians who have studied this period in assessing the Framers' understanding of executive power. Of course, The Executive Power over Foreign Affairs and The Original Understanding of War Powers do rely on the works of leading intellectual historians and, as discussed, TWP builds upon the foundation they provide. Further, Professor Yoo writes as if leading historians have examined the pre-Convention period and found that its trends lead inevitably to his conclusion that war powers are presidential powers. No historian that Professor Yoo cites, nor any other of which I am aware, has said this. None has directly addressed the question of war powers, and, moreover, this is not the way historians view history. Historians also differ in their emphases. Professor Gordon Wood, upon whom Professor Yoo principally relies, emphasizes the founders' renewed enthusiasm for executive power in the 1780s. Professor Jack Rakove, about whom Professor Yoo has relatively little to say, emphasizes that the drafters came to their final version of a powerful independent chief executive late in the drafting process and in spite of strong reservations. Compare Jack N. Rakove, Original Meanings 256-68 (Random House 1996) (describing the debates that led to the strong executive), with Gordon Wood, The Creation of the American Republic, 1776-1787 549-53 (North Carolina 1969) (arguing that a chief goal of the convention was to make the executive both independent and powerful). In any event, I am sure that neither Professor Wood nor Professor Rakove would claim that any particular view of the Declare War Clause is compelled by their work. 
sary to maintain a war effort, Professor Yoo says that the Framers must also have seen it that way.

But Professor Yoo constructs this historical inevitability only through the inevitable selective emphasis. True, the Framers were greatly influenced by writers such as Locke, Montesquieu, and Blackstone-but they often rejected their teachings, especially on the subject of unified executive foreign affairs power. True, the Framers were greatly influenced by the English practice in foreign affairs, which assigned war-initiation to the executive-but they also knew of other models, such as the Roman Republic, which assigned it to the legislature. True, many leaders of the late 1780 s sought a reinvigorated executive after the unsatisfactory experience of the first decade of independence, but many of these same leaders thought that the new executive power should not extend to "war and peace." As a result, Professor Yoo's account of executive war powers, based on the historical and intellectual background of the Convention, shows nothing more than what the Framers might have done. This does not give us ground for preferring one possible reading of the Declare War Clause over another. What the clause means depends upon close attention to how its words were used in the eighteenth century and how it fits within the larger structure of the Constitution, not upon extrapolating some inevitable meaning from its historical antecedents.

\section{The Commander-in-Chief Clause.}

Professor Yoo also relies to some extent upon the Commanderin-Chief Clause, although it is unclear what he thinks it adds to the Executive Power Clause. The President's possession of the commander-in-chief power is not inconsistent with Congress's possession of the war-initiation power. As argued in TWP, it is plausible to view the Declare War Clause (applied to acts) as a specific exception to the commander-in-chief power, just as it is plausible to view the Declare War Clause (applied to proclamations) as a specific exception to the President's diplomatic power. Thus, even if the ordinary pre-1787 understanding of the commander-in-chief power in theory included warinitiation power, it might still be the case that the Declare War Clause includes war-initiation power (and thus limits the commander-in-chief power).

59 I should be clear that this criticism is directed to War and Constitutional Text, not to Original Understanding of War Power. The latter work, for which I have much respect, offers a textual and structural account of the Declare War Clause. See generally Yoo, 84 Cal L Rev 167 (cited in note 4). But when TWP calls that account into question, War and Constitutional Text responds not by attempting to rehabilitate it, but by claiming that whatever the Declare War Clause means, the Framers could never have intended to transfer war-initiation power to Congress. See Yoo, 69 U Chi L Rev at 1654 (cited in note 6). 
In any event, however, Professor Yoo has not shown that the ordinary eighteenth-century understanding of the commander-in-chief power included war-initiation power. Indeed, several of his favored authorities stand squarely against it, and show to the contrary that war-initiation was a separate part of the executive power, distinct from the commander-in-chief power. Blackstone, for example, described the power to "make war and peace" as part of the "principal prerogatives of the king respecting this nation's intercourse with foreign nations"a category in which he also included diplomatic power and treatymaking power. ${ }^{60}$ In a different section of the Commentaries, he described what amounted to the commander-in-chief power (although he did not use the exact phrase) as one of the monarch's "domestic powers": The king, Blackstone said, is "the generalissimo, or the first in military command, within the kingdom" and "[i]n this capacity," in other words, as generalissimo, the king had the power of "raising and regulating fleets and armies" and "sole supreme government and command of the militia within all his majesty's realms and dominions, and of all forces by sea and land, and of all forts and places of strength.," In short, Blackstone's commander-in-chief power referred to command of the army in a narrow sense, not to control over relations with other countries, which was part of the external executive power. Similarly Montesquieu described the power to "make[] peace and war" as part of the "executive power," not part of the power to command the army. ${ }^{62}$

The precedent of the Articles of Confederation, on which Professor Yoo relies in other contexts, also shows that the commander-inchief power was distinct from war-initiation power. Under the Articles, the Continental Congress had the sole power to "determine on" war and peace and (separately) the power to appoint a commander-inchief. $^{63}$ In both cases, a supermajority of nine states was required. Presumably, the commander under the Articles, once appointed, would not have had the war-initiation power, as that would have impinged upon Congress's power of initiation, and would have rendered irrelevant the supermajority requirement for engaging in war. Rather, the Articles, like Blackstone, saw the commander-in-chief power as con-

60 William Blackstone, 1 Commentaries on the Laws of England $* 250,253$ (Chicago 1979).

61 Id at $\approx 254$. Professor Yoo misspeaks in saying that "as the undisputed commander-inchief of all military forces, the King could make war at his discretion." Yoo, $69 \mathrm{U}$ Chi L Rev at 1649 (cited in note 6). As Blackstone makes clear, it was not the King's commander-in-chief power, but his executive power that contained the authority to initiate war.

62 Montesquieu, The Spirit of the Laws at 156-57 (Cambridge 1989) (translated and edited by Anne M. Cohler, Basia Carolyn Miller, and Harold Samuel Stone).

63 Articles of Confederation, Art 9. 
cerning the chain of command, not the use of the army to initiate war.

3. The failure to explain the narrow reading of declaring war.

Most problematic for Professor Yoo is his inability to provide a satisfactory account of how the Declare War Clause itself, read narrowly, fits into the constitutional structure. As discussed, the eighteenth century would have understood the formal proclamation as a useful but dispensable tool of international relations. Its principal purpose was to notify: advising citizens, neutrals, and enemies that a war had broken out, and explaining the reasons (real or pretextual) for the hostilities. It was, as I have said, an important communicative and rhetorical device. ${ }^{65}$

As argued in $T W P$, if this is what the formal proclamation was, it is very hard to fit into the structure of the Declare War Clause. Professor Yoo would have it that the President can begin a war, but only Congress can make an official notification of it. So conceived, the clause is not a check on the President's ability to formulate and carry out military policy, but a check on the President's ability to announce military policy. This seems illogical, particularly in foreign affairs, where it is generally understood that the executive and not Congress is the sole communicative organ. Moreover, it could not be an effective check, given the President's control of the channels of diplomatic communication. How would it be decided when the President's international communications about military policy amounted to a formal declaration, such that Congress would need to be involved? Nothing in the intellectual history of separation of powers or the constitutional generation's understanding of the relative spheres of the branches of government would support dividing power in this manner. ${ }^{66}$ Nor is

64 The Constitution's drafting history also suggests that the founding generation did not read the commander-in-chief power broadly to include war initiation power. In the draft prepared by the Convention's Committee of Detail, Congress had the power to "make war" (later changed to "declare war" by the Convention as a whole); in the same draft, the President had the commander-in-chief power (as in the final version). See Farrand, 2 Records at 182, 185 (cited in note 50). Since the Committee evidently had the idea that Congress would initiate ("make") war, it must have conceived of the commander-in-chief power as a different power.

Professor Yoo's suggestion that commander-in-chief power conveyed war-initiation power is also not supported by any founding-era commentary. Indeed, for all Professor Yoo complains about TWP ignoring the Commander-in-Chief Clause, he does not provide any eighteenthcentury evidence that it means what he says it means. He does make some reference to what Presidents Truman and Nixon claimed it meant, but it is hard to see what this has to do with the clause's original meaning.

65 See Ramsey, 69 U Chi L Rev at 1586 (cited in note 1).

66 For example, Professor Yoo, relying on Blackstone, says that the proclamation "served the purpose of notification that hostile actions were legal because authorized by the sovereign." Yoo, $69 \mathrm{U}$ Chi L Rev at 1653 n 38 (cite in note 6). But why would anyone think that Congress 
there anything in practice, either near the time of the founding or otherwise, in support of that. Presidents always have been understood to have the power to announce that military action is taken on their behest, with specified motivations and objectives, and no one has ever thought that such announcements were in themselves constitutionally problematic. Professor Yoo simply cannot explain what power he thinks the Declare War Clause transfers from the President to Congress, or why the Constitution made such a shift. ${ }^{67}$

As discussed, advocates of presidential war powers previously had a fairly good response to this structural objection, based on the argument that the formal declaration was prerequisite to invoking the laws of war. ${ }^{63}$ Given the Framers' vision of separation of powers, one might understand a division of authority that allocated the legislative aspects of war to Congress (that is, the decision to invoke or not to invoke the laws of war), while leaving the executive/military aspects of war (the decision whether and how to commit troops) to the President. This, one might say, actually does a purer job of dividing executive and legislative responsibilities than the English system, which gave everything to the executive. It also makes the Declare War Clause line up better with the Marque and Reprisal Clause, which is also about invoking the laws of war to distinguish privateers from pirates. At least, with this interpretation, one can tell a plausible story about why the Declare War Clause was drafted as it was.

A central point of TWP is to reject this explanation of the Declare War Clause, on the ground that ordinary eighteenth-century usage did not understand a formal declaration of war to be necessary to invoke the laws of war. ${ }^{6 \%}$ Professor Yoo appears in his Response largely to concede the point. ${ }^{70}$ But this leaves him with no explanation of what the Declare War Clause was intended to accomplish, or why the constitutional generation would have thought it an appropriate

was the appropriate body to decide whether to give such a notification, particularly when the President controlled the organs of diplomacy, commanded the military, and initiated the hostilities?

67 Professor Yoo mischaracterizes this argument as claiming that, absent a broad reading of the Declare War Clause, Congress would not have any effective check on the President. To the contrary, Professor Yoo has done important work in showing the extent to which the Framers believed Congress's control over funding provided an effective check on presidential power. Rather, TWP's structural claim is that, absent a broad reading of the Declare War Clause, there is no way to explain the purposes underlying the Declare War Clause itself. Why was the power of notifying others that a war had begun thought to be a legislative function? Professor Yoo has not provided any answer to this question.

68 See Yoo, 84 Cal L Rev at 242-43 (cited in note 4) ("[A] declaration of war performed a primarily juridical function under eighteenth-century international law, and it was this understanding that the Framers drew upon in giving Congress the authority to declare war.")

69 Ramsey, $69 \mathrm{U}$ Chi L Rev at 1585-86 (cited in note 1).

70 See Part I.B. 
way to divide powers. Professor Yoo spends much time on the currents of history, and upon other parts of the Constitution, but he does not give a coherent account of the Declare War Clause itself. Yet if we lack an explanation for why the Framers would have chosen the narrow meaning of declaring war, that is good reason to prefer the broad meaning.

B. The Case Against the Broad Meaning of the Declare War Clause

1. Other clauses of the Constitution.

I now turn to Professor Yoo's argument that important textual and structural evidence is inconsistent with a broad reading of the Declare War Clause. Professor Yoo first points to three clauses in the Constitution itself that he says are inconsistent with a broad meaning of "declare war": Article III's Treason Clause; Article I, Section 10; and Article I, Section 1's Marque and Reprisal Clause."

By Article III, treason consists of "levying war" against the United States. ${ }^{2}$ According to Professor Yoo, if the Framers had meant the Declare War Clause to limit presidential war-making powers, they would have used language parallel to the Treason Clause. That does not follow at all, however, because the Constitution's limitation on individuals warring against the United States is much broader than its limitation on the President warring on behalf of the United States. To pick one example, the Declare War Clause (as explained in TWP) does not limit the President's independent ability to conduct a defensive war. In contrast, an individual who fought against the United States in a war that the United States started (that is, who fought a defensive war against the United States) would surely be "levying war" against the United States and hence be guilty of treason. Had the Framers substituted "levy" for "declare" in Article I, Section 8, it would limit the President's ability to respond to an attack, which is not what was intended.

Professor Yoo's Article I, Section 10 argument has similar flaws. That clause prohibits the states from "engaging in war" unless invaded, or congressionally authorized. ${ }^{73}$ Professor Yoo says this limitation on state war power is parallel to TWP's view of the Declare War Clause's limitation on presidential war power, and that therefore the Declare War Clause, if it meant what TWP says it did, should have used language parallel to Article I, Section 10. Again, a prohibition upon "engaging" in war unless invaded does not capture TWP's un-

73 US Const Art I, \& 10, cl 3 . 
derstanding of the President's war power. The President (unlike the states) can independently carry on a war that is formally declared by a proclamation of the opposing side, that is declared by an attack on U.S. forces abroad, or that is directed against a nation that has declared support for an enemy of the United States, even if the United States has not been invaded. ${ }^{74}$ In short, the trigger for a state's independent war power is invasion (or immediate threat); the trigger for the President's independent war power is a formal declaration or act of war by the opposing side, which includes, but is not limited to, an invasion. The two restrictions are not parallel, and thus it is perfectly understandable that they use different language.

The Marque and Reprisal Clause of Article I, Section $8,{ }^{75}$ far from supporting Professor Yoo, stands squarely against his interpretation. It gives Congress the power to authorize a limited form of offensive war against another nation, and (as Professor Yoo appears to agree) it also denies that power to the President. This is entirely consistent with a broad reading of declaring war: The Marque and Reprisal Clause gives Congress authority over a limited form of war, while the Declare War Clause gives Congress control over broader forms of war. In contrast, Professor Yoo's reading of the Declare War Clause would give Congress control over a limited category of hostilities, and give the President control over the broader category. Prior to the Constitution, all war-making power, including marque and reprisal power, was understood to be executive. ${ }^{76}$ Therefore, Professor Yoo must believe that the Constitution went out of its way to take marque and reprisal power away from the President, and yet left the President with the broader war power. This makes no sense, for a President who wished to seize property of the enemy could presumably start a war and order seizure incident to the executive war-making power. Professor Yoo cannot explain what separation of powers purpose is served by denying the President the lesser power but not the greater, whereas under TWP's interpretation, Congress's marque and reprisal power is a logical corollary to its war power. ${ }^{n}$

74 See Ramsey, 69 U Chi L Rev at 1626-27 (cited in note 1).

75 US Const Art I, \& 8, cl 12.

76 See Ramsey, 69 U Chi L Rev at 1599 (cited in note 1) (establishing that marque and reprisal was an executive power).

77 Oddly, Professor Yoo describes the Marque and Reprisal Clause as concerning "the power of Congress to recognize or declare the legal status and consequences of certain wartime actions, and not the power to authorize those actions." Yoo, $69 \mathrm{U}$ Chi L Rev at 1667 (cited in note 6). But the clause does not bear Professor Yoo's attempt to force it into alignment with his view of wide presidential war powers. Surely the plain meaning of the Clause is that Congress and not the President can direct that foreign property be seized in satisfaction of an injury. 


\section{Precedents.}

Professor Yoo points to several sources outside the text itself that are important precedents for constitutional phrasing. ${ }^{78}$ But none forecloses a broad meaning of the Declare War Clause. Under the Articles of Confederation, for example, all powers of war and peace were lodged in a single body, the Continental Congress, which had the power to "determine on" war and peace. ${ }^{79}$ Professor Yoo says that the Framers should have used this language in the Declare War Clause, had they meant to give the new Congress an exclusive power over initiating hostilities. Again, Professor Yoo's proposed language does not capture what TWP understands "declare war" to mean. For example, a Congress with the power to "determine on" war might claim the sole power to decide whether to respond to the declaration of war (by proclamation or act) by another nation. As explained in TWP, Congress's power to "declare war," in contrast, does not extend so far.

The only source in which Professor Yoo finds something synonymous with TWP's view of the Declare War Clause is the South Carolina Constitution of $1778 .^{80}$ By this constitution, the executive could not "commence" war, which captures a similar idea to the broad meaning of "declare" war. I think we must agree that this counts somewhat in Professor Yoo's favor. I do not, however, find it conclusive. "Commence" is somewhat ambiguous as to how it allocates the power to respond to an attack or formal declaration: Does "commence war" refer to beginning the legal state of war, or beginning actual military participation in the war? (On the other hand, even the broad reading of "declare" is a little troublesome on this point, as explained in $T W P^{81}$ ) More importantly, the fact that one fairly obscure foundational document used a different synonym to express the same concept is not decisive. It is the nature of synonyms that they are used interchangeably. The fact that the Framers could have used a different phrase to express their meaning does not show that they had to do so.

Professor Yoo also argues that the New York, Massachusetts, and New Hampshire constitutions in particular served as models for the U.S. Constitution, and none of them contained any express limitation on executive war-initiation abilities (other than funding). But the state constitutions, especially ones drafted later in the revolutionary period, are not especially useful models on the particular question of warinitiation. Particularly after the drafting of the Articles of Confedera-

78 Yoo, 69 U Chi L Rev at 1668-69 (cited in note 6).

79 Articles of Confederation, Art 9.

80 South Carolina Const Art XXXIII (1778), reprinted in Francis N. Thorpe, ed, 6 The Federal and State Constitutions, Colonial Charters, and Other Organic Laws 3255 (GPO 1909).

81 Ramsey, 69 U Chi L Rev at 1598-99 (cited in note 1). 
tion, it was understood that the national government, not the states, would have control of war-initiation. The fact that the issue was not addressed in the later state constitutions thus proves little. ${ }^{82}$ And although the Framers in Philadelphia may have looked to these constitutions in general, they likely did not think of them as complete models of war power.

\section{Structure.}

Professor Yoo's final claim against the broad meaning is that the Constitution is clear in other areas where it intends to limit the President's exercise of a traditional executive power, such as treatymaking and appointments. ${ }^{84}$ In other words, if the drafters really meant what TWP says they did, surely there are much clearer ways of expressing it. I agree that the Declare War Clause is a poor bit of draftmanship, whatever it means. I also agree that we should favor the simplest and most natural reading of constitutional language over contorted and artificial readings. But Professor Yoo's argument is not decisive for two reasons. First, the Constitution is not an ideal document, and it contains some awkward phrasing. It is certainly not out of the question that the Framers failed to choose the best possible language to express their views of war power. Unlike the Treaty and Appointments Clauses, which were drafted in the calmer reflection of committees, the Declare War Clause was written (or rather rewritten) in haste, toward the end of the Convention, in response to objections raised from the Convention floor. ${ }^{25}$ As Professor Yoo himself says, it was the prod-

82 Moreover, the U.S. Constitution does depart from the cited state constitutions, by giving the power of declaring war (whatever that may mean) to Congress.

83 Professor Yoo also argues that the precedent of the Declaration of Independence shows that the founding generation would have understood a declaration as a formal document. True, the Declaration of Independence is an example of a formal declaration. TWP does not deny that there was such a concept, or that it had an important (though not mandatory) role in eighteenthcentury international relations. But the existence of the Declaration does not show anything about whether the term "declare" can also encompass an act as well as a formal statement.

I am unsure how to read Professor Yoo's observation that TWP “diminishes" the Declaration. Surely the Declaration played exactly the role Professor Yoo and I agree the formal declaration of war played: It was a useful, but not necessary, communicative and rhetorical device. Such devices, however, can have enormous impact. To the extent Professor Yoo suggests that the Declaration had a mandatory role (that is, that it was prerequisite to recognition of the United States as a separate nation under international law, rather than a collection of rebellious subjects), I think he probably does overstate its importance. The United States likely could have "declared" independence by acts severing ties with England, although this would not have had the rhetorical and communicative force of the Declaration.

84 See Yoo, 69 U Chi L Rev at 1674-75 (cited in note 6).

85 See Rakove, Original Meanings at 244-87 (describing evolution of the drafters' view of presidential powers) (cited in note 58); Farrand, 2 Records at 318-19 (describing the redrafting of the Declare War Clause) (cited in note 50). 
uct of an "obscure, garbled, last-minute debate." prise that it does not work as well as provisions drafted more carefully.

More importantly, in constitutional interpretation ultimately one must pick between competing meanings. The question is not whether one interpretation solves every imaginable problem that can be charged against it, but whether it does a better job of solving problems than a competing meaning. Here Professor Yoo's failure to advance a coherent alternative account of the Declare War Clause is of central importance. As explained in the previous section, Professor Yoo says that the Declare War Clause refers only to a proclamation, but he does not explain how that produces a workable structural reading of the clause.

\section{RATIFICATION AND POST-RATIFICATION HISTORY}

TWP takes as one point of departure the apparent paradox of war powers: that the political leaders of the 1790s (many of whom were Convention delegates) seemed to assume a limitation on presidential war powers that is not immediately evident from the Constitution's text. ${ }^{88}$ Specifically, they appeared to assume that Congress and not the President had the primary power to commit the nation to war. For example, Madison and Hamilton, in their spirited 1793 PacificusHelvidius debates, sharply disagreed over the scope of the executive power of the President in foreign affairs, but they did agree that whatever else its scope, it did not include committing the nation to war, as that was a congressional prerogative. ${ }^{8}$ And yet, if we think of the power to "declare war" as meaning only a formal proclamation (as is its most usual connotation today), it is difficult to explain how Madison, Hamilton, and others reached their common understanding of the Constitution's text. ${ }^{\text {so }}$ Something more must be done to explain the 1790 s thinking about war power.

This point of departure is troublesome for Professor Yoo from the beginning, because he denies the central paradox of the Declare War Clause. Rather, he places near-complete reliance on the ratifica-

\footnotetext{
86 Yoo, 69 U Chi L Rev at 1656 (cited in note 6).

87 A stronger way to put Professor Yoo's objection is that the broad meaning of declare war was probably not the phrase's primary connotation. As conceded in TWP, it may have been the case that the most common eighteenth-century usage referred to a proclamation, with a secondary meaning encompassing acts as well as proclamations. Other things being equal, I agree that we should prefer the more common meaning in a case where two meanings are available. As discussed in $T W P$, however, I think the most common meaning does not supply a plausible fit with the Declare War Clause.

88 See Ramsey, 69 U Chi L Rev at 1606 (cited in note 1).

89 For an expanded discussion of this exchange, see Part III.B.

90 See Yoo, 84 Cal L Rev at 242 (cited in note 4).
} 
tion debates to the exclusion of other contemporaneous evidence." As I shall explain below, the ratification debates do not show what Professor Yoo thinks they show. But the more serious problem is that his approach allows him to ignore the evidence of the 1790s, and thus to wrap up his story of war powers in a neat package that does not take into account everything the Framers said on the matter.

The decision to ignore the evidence of the 1790s might be understandable (though a little idiosyncratic) if Professor Yoo actually stuck to it. But as his Response makes clear, he is willing to peek into the evidence of the 1790s when it supports his view. Thus he relies heavily on Hamilton's Pacificus, where Hamilton makes broad statements about the scope of executive power, while ignoring (among others) Hamilton's comments (in the same Pacificus essays) about war power. This selective use of the post-ratification evidence, together with overreading of the ratification evidence, allows Professor Yoo to escape the central interpretive claim of TWP: that the broad reading of declaring war provides a better fit with ratification and post-ratification history than does the narrow reading.

\section{A. Ratification}

For Professor Yoo, the ratification debates, and particularly the ratification debates in key states such as Virginia, are the critical indicia of constitutional meaning, to the near-total exclusion of everything that happened after 1789. As discussed below, I think his focus is far too narrow, and allows him to avoid key evidence of constitutional meaning that is inconsistent with his view of war powers. But, in any event, Professor Yoo's ratification arguments fail on their own terms. According to Professor Yoo, the smoking gun here is found in the records of the Virginia convention. In his telling, the Anti-Federalist Patrick Henry raised the issue of the President's war power, and the Virginia Federalists responded not by pointing to the limitations of the Declare War Clause, but by pointing to Congress's control of appropriations. From this, Professor Yoo concludes that no one thought the Declare War Clause was a material limitation on presidential war power.

91 See Yoo, 69 U Chi L Rev at 1656-60 (cited in note 6). See also Yoo, $70 \mathrm{U}$ Colo L Rev at $1171,1173-74$ (cited in note 6) (discounting post-ratification history); Yoo, 84 Cal L Rev at 24749 (cited in note 4) (focusing on ratification debates).

92 Indeed, the debates are so important to him that they even precede his discussion of the text in his Response. See Yoo, $69 \mathrm{U}$ Chi L Rev at 1660 (cited in note 6). This is consistent with Professor Yoo's emphasis in prior works. See John C. Yoo, Globalism and the Constitution: Treaties, Non-Self-Execution, and the Original Understanding, 99 Colum L Rev 1955, 2040-74 (1999) (focusing on the ratification debates in discussing treaty power); Yoo, $84 \mathrm{Cal} \mathrm{L} \mathrm{Rev} 167$ (cited in note 4) (focusing on the ratification debates in interpreting war power).

93 See Yoo, U Chi L Rev at 1657-59 (cited in note 6). The debate is recorded in John P. 
The problem with this argument is that Henry's challenge had nothing to do with war powers. Henry's point was that the President, as commander-in-chief of the army, could accomplish a domestic coup d'état and make himself king." Henry was not complaining about presidential initiative in overseas adventures. He did not mention war against foreign nations once in the entire passage Professor Yoo quotes. The Federalists did not respond by pointing to the Declare War Clause, because no matter how broadly one reads that clause it is not a protection against a President's internal malfeasance. The Federalists pointed to appropriations, because that is one central check upon a commander-in-chief's domestic misuse of the military: An army is much more likely to follow the body that pays it. ${ }^{95}$

Apparently this passage from the Virginia convention is Professor Yoo's best evidence, but it shows nothing like the broad presidential war powers he advocates. In my own review of the ratification debates I have found no passage in which anyone asserted broad presidential war powers, and Professor Yoo has not pointed to any such passage. Moreover, by focusing on the Virginia convention in isolation, Professor Yoo avoids a broader theme of the ratification debates, discussed in detail in TWP. The Anti-Federalists did make broad challenges to the Constitution's vision of presidential authority, and the Federalists responded by saying that the President's powers were not as great as the Anti-Federalists supposed. ${ }^{96}$ Among other points, the Federalists noted in this context that the President did not have the power to declare war. True, they did not explain what declaring war meant. But in order to make their claim credible, they must have believed (and thought their audience believed) that lacking the power to declare war amounted to the lack of a material power.

Kaminski and Gaspare J. Saladino, eds, 9 The Documentary History of the Ratification of the Constitution 951-68 (State Historical Society of Wisconsin 1990) (Henry's speech of June 5, 1788), and John P. Kaminski and Gaspare J. Saladino, eds, 10 The Documentary History of the Ratification of the Constitution 1281-82 (State Historical Society of Wisconsin 1993) (speeches in response, June 14,1788 ).

94 See Kaminski and Saladino, 9 Documentary History at 964 (cited in note 93).

95 As Professor Yoo has elsewhere acknowledged, when Henry did speak about war powers, he indicated that Congress had the war-initiation power. See Yoo, $84 \mathrm{Cal} \mathrm{L}$ Rev at 281-82 (cited in note 4) (quoting Henry's speech to the Virginia convention); Jonathan Elliot, ed, 3 The Debates in the Several State Conventions on the Adoption of the Federal Constitution 172 (2d ed 1836). Professor Yoo thinks Henry must have been mistaken in these comments, since (in his view) they conflict with Henry's later comments about the dangers of the President. But in fact the comments are perfectly consistent: Henry thought Congress had the war-initiation power, but the President was dangerous domestically because the President commanded the army. Henry's fear was not that the President would order the army to attack a foreign nation, but that the President would order the army to overthrow the U.S. government.

96 See Ramsey, $69 \mathrm{U}$ Chi L Rev at 1549, 1604 (cited in note 1) (quoting statements by, among others, Hamilton in The Federalist, and Iredell at the North Carolina convention). 
As argued in TWP and above, lacking the power to issue a formal proclamation does not amount to a material limitation on presidential initiative, giving the formal proclamation its eighteenth-century meaning as a non-obligatory means of communication. ${ }^{97}$ This is not because the formal proclamation was "useless," as Professor Yoo wrongly accuses TWP of arguing, but because anything that could be accomplished by formal proclamation the President could (in Professor Yoo's view) accomplish by other means. Professor Yoo's President can initiate a legal state of war by ordering an armed attack, and presumably can accomplish the communicative and rhetorical features of the formal proclamation through control of the channels of diplomacy. The participants in the ratifying debates must have thought that the Declare War Clause meant something more than just a formal proclamation, for otherwise the Federalists' arguments on this ground make no sense. This is where TWP makes its contribution, for it shows that there is a meaning of the constitutional text in support of this broad understanding. In short, to the extent there is evidence from the ratification period, it more strongly favors the view expressed in $T W P$.

\section{B. The Evidence of the 1790 s}

I now turn briefly to the post-ratification period. Professor Yoo largely ignores the evidence of the 1790s, on the strength of his claim that the ratification debates alone fix constitutional meaning. As an interpretive matter, I simply disagree with this view. As TWP frames the inquiry, the question is not the subjective beliefs of any particular ratifiers (or drafters), but the objective meaning of the phrases used in the Constitution, as they would have been understood by informed observers at the time." To be sure, the ratification debates are one crucial source in this inquiry, for they provide evidence of the meaning the ratifiers (who were informed observers of the time) gave the relevant text. But I do not see what is gained by artificially limiting the inquiry

97 See Part II.

93 This point illustrates how my analysis differs from much traditional pro-Congress scholarship. I do not argue that, because Hamilton, Iredell, etc., said that lacking the power to declare war was a material limitation, we must read the Declare War Clause to be a material limitation, whatever its literal meaning. Rather, my view takes the text first: We first establish that there are two plausible meanings of the clause, one which provides a material limitation upon presidential war power and one that does not. Once this range of textual meanings is established, the ratification statements, which assume that the clause did establish a material limitation, are evidence in favor of choosing one of the permissible meanings of the text over the other. The point is important, because a leading criticism of pro-Congress scholarship is that it departs from the literal meaning of the text to give effect to Framers' intent. TWP shows that this does not need to be the case.

99 See id at $1553-54$. 
to the ratification period. As in the ratification debates, the Constitution's text was also closely studied and expounded in the 1790s by informed leaders familiar with its context and ordinary meaning. True, the interpreters of the 1790 s were subject to political and practical pressures that may have biased their readings; they could make simple mistakes in their interpretations, and they often did not agree. Thus what they said about the text must be examined carefully and not taken at face value or out of context. But all this is also true of the ratifiers, who were engaged in a political struggle, formed disparate views of the Constitution, and advanced some downright silly interpretations of its language. I do not see anything that greatly privileges the ratifiers over their contemporaries, if one is searching for the best objective meaning of the text. ${ }^{100}$

I shall not restate all of the evidence of the 1790s, as it has been adequately explored by prior scholarship, and I refer to it in summary form in TWP..$^{101}$ Moreover, Professor Yoo does not contest in his Response that important leaders of the 1790s appeared to think that Congress alone had the power to commit the nation to war. Prior to $T W P$, his argument was that this was not decisive, because these views could not be tied to any language in the Constitution. But TWP has shown that this is not true: There is a plausible meaning of the text that produces the result the leaders of the 1790s appeared to assume. Once that link is established, the evidence of the 1790 s becomes powerful evidence for preferring one meaning to another that is not consistent with post-ratification evidence.

Professor Yoo does not entirely ignore the post-ratification history in his Response to TWP, but he makes peculiar use of it. He does not discuss the evidence I and others have presented, in which the commentary of the 1790s directly addresses war powers. He does, however, rely on post-ratification statements from political leaders such as Jefferson, Hamilton, and Marshall in support of the more general claim that the President's Article II, Section 1 "executive Power" includes power over foreign affairs. ${ }^{102}$ I have no quarrel with these quotes nor this conclusion, and indeed both the conclusion and the quotes appear in The Executive Power over Foreign Affairs. ${ }^{103}$ But Professor Yoo claims that these quotations also imply broad presidential

100 A more difficult question is how far beyond the 1790 s one may safely go in searching for evidence of a phrase's ordinary meaning in the 1780 s. I agree with Professor Yoo that looking deep into the nineteenth century may lead to reliance on sources too temporally distant to be indicative of eighteenth-century meaning. Yet is seems arbitrary to establish any particular cutoff date. In any event, looking a decade or so beyond the 1790 s would not likely lead to different conclusions with respect to war powers.

101 See Ramsey, 69 U Chi L Rev at 1606-08 (cited in note 1).

102 See Yoo, $69 \mathrm{U}$ Chi L Rev at 1678 (cited in note 6).

103 Prakash and Ramsey, 111 Yale L J at 305, 330 (cited in note 14). 
war powers. This is a highly selective use of post-ratification history, for Professor Yoo does not mention that when these same leaders discussed war-initiation specifically, they called it a congressional power.

For example, Professor Yoo quotes Hamilton's Pacificus essay to the effect that, as a general matter, foreign affairs power is an element of executive power. ${ }^{104} \mathrm{He}$ further relies on Pacificus's maxim that allocations of foreign affairs power away from the President are to be construed strictly, which (Professor Yoo says) compels a narrow reading of the Declare War Clause. Professor Yoo does not acknowledge, however, that in the same section of the same essay Hamilton said that despite the general proposition that foreign affairs power is an element of executive power, and despite the maxim that limitations on executive power are to be construed strictly, under the Constitution Congress alone has the power to place the nation in a state of war. Hamilton wrote:

It deserves to be remarked, that as the participation of the Senate in the making of treaties, and the power of the Legislature to declare war, are exemptions out of the general "executive power" vested in the President, they are to be construed strictly, and ought to be extended no further than is essential to their execution.

While, therefore, the Legislature can alone declare war, can alone actually transfer the nation from a state of peace to a state of hostility, it belongs to the "executive power" to do whatever else the law of nations, co-operative with the treaties of the country, enjoin in the intercourse of the United States with foreign Powers.

In this distribution of authority, the wisdom of our Constitution is manifested. It is the province and duty of the executive to preserve to the nation the blessings of peace. The Legislature alone can interrupt them by placing the nation in a state of war. ${ }^{105}$

Hamilton's point was that even though Congress had the exclusive power to place the nation in a state of war, the President retained other foreign affairs powers that had some connection with war-in the particular case, the power to decide upon a policy of neutralityas part of the executive power.

104 See Yoo, $69 \mathrm{U}$ Chi L Rev at 1677-78 (cited in note 6). The original source is reprinted in Alexander Hamilton, Letters of Pacificus No 1, in Henry Cabot Lodge, ed, 4 The Works of Alexander Hamilton 432 (G.P. Putnam's Sons 1904).

105 Pacificus No 1, in Lodge, ed, 4 Alexander Hamilton at 443 (cited in note 104).

106 Id at 437-39. As shown in TWP, this was not a view Hamilton adopted merely for the sake of argument, but is consistent with his views expressed earlier as Publius and later as Lucius 
This passage can only be taken as an endorsement of the broad meaning of "declaring" war. As discussed in TWP, Hamilton surely believed that an armed attack on another nation (as well as a formal proclamation) would place the United States in a "state of war." Moreover, he surely did not believe that a formal proclamation was prerequisite to an armed attack. ${ }^{108}$ Yet he located all of the power to place the nation in a state of war with Congress. This must have been because he equated "declaring" war with "placing the nation in a state of war," which he could only do if he thought wars could be "declared" by armed attack as well as by proclamation. In short, Professor Yoo's suggestion that the Pacificus essay supports presidential war power takes Hamilton's statements badly out of context. ${ }^{100}$

It is also worth noting that the broader context of the Pacificus essay shows a general consensus in favor of exclusive congressional war-initiation powers. Indeed, that was the starting point for the entire debate. In the spring of 1793, President Washington, without consulting Congress, announced that the United States would remain neutral in the war between Britain and France, even though the United States had a treaty of alliance with France and many of its citizens sympathized with the new French republic. ${ }^{110}$ Some voices-notably the essayist "Veritas" - argued that even this limited measure transgressed upon Congress's exclusive war power." Hamilton, writing as Pacificus, defended the administration. Of course, the easiest response, had it been credible, would have been to say that Congress did not have exclusive war powers, but rather shared them with the President; if true, that would surely show that Washington had not overreached. But, as shown above, Hamilton did not take that approach-presumably be-

Crassus. See Ramsey, 69 U Chi L Rev at 1607 (cited in note 1).

107 See Ramsey, 69 U Chi L Rev at 1606-07 (discussing the ordinary understanding of how a state of war was created in the eighteenth century) (cited in note 1).

108 See Federalist 25 (Hamilton), in Clinton Rossiter, ed, The Federalist Papers 162-67 (Mentor 1961).

109 Professor Yoo also makes the gratuitous suggestion that TWP's treatment of war power is inconsistent with my conclusion in The Executive Power over Foreign Affairs that the President's executive power extends to treaty termination. See Yoo, $69 \mathrm{U}$ Chi L Rev at 1678 (cited in note 6) ("A consistent approach to the constitutional structure and executive power in foreign affairs ought to find presidential authority both to initiate military hostilities and to terminate treaties."). He relies, of all things, on Hamilton's Pacificus to support that view. Yet Professor Yoo must surely know that Hamilton thought the President had the power to terminate treaties but not the power to involve the nation in war. See Prakash and Ramsey, 111 Yale L J at 324-27 (cited in note 14) (discussing Hamilton's view of treaty termination). My "inconsistency" was Hamilton's as well.

110 See Prakash and Ramsey, 111 Yale L J at 328-39 (cited in note 14), and historical works cited therein.

111 On the Veritas essay, see Stanley M. Elkins and Eric McKitrick, The Age of Federalism 343-44, 360-61 (Oxford 1993) (dismissing the idea of Jefferson as Veritas and describing Hamilton's response as Pacificus to Veritas). 
cause he knew it was not credible. Instead, he conceded Congress's exclusive war power, but defined it precisely as the power to place the nation in a state of war. Since Washington had not done that, Hamilton said, Congress's exclusive war power was not infringed.

Yet even this relatively modest view of presidential war power drew a sharp response from James Madison, writing as Helvidius. ${ }^{12}$ Madison started from the same assumption as Hamilton: that the power to commit the nation to war was an exclusive power of Congress. But Madison defined the power more broadly, saying that it was for Congress to decide what was and was not a ground for war. By setting the United States on a neutral course, Madison said, the President had implicitly resolved that there were no grounds for war, and that preempted what should have been a congressional decision. ${ }^{113}$ Notably, Madison as Helvidius focused on showing that the President had exercised a power of war; he assumed that if the President had exercised a power of war, that would be unconstitutional. Presumably this was because his audience (and indeed his opponent Pacificus) took that for granted.

TWP does not argue that because Hamilton and Madison (and their audience) appeared to assume Congress had control of the decision to commit the nation to war, the Declare War Clause must be given that effect without regard to its literal meaning. ${ }^{114}$ Rather, because "declare war" had two distinct meanings in eighteenth-century usage, TWP argues that we should prefer the meaning that is consistent with the understanding of the 1790s. The evidence of the 1790 s does not create the meaning of the Declare War Clause, but it helps us decide which of two possible meanings was the one the founding generation understood. Professor Yoo, on the other hand, asks us to ignore the evidence of the 1790s altogether (except, apparently, when it supports his view of executive power).

112 See James Madison, Letters of Helvidius, No 1, in 1 Letters and Other Writings of James Madison 612, 612-621 (J.B. Lippincott 1867).

113 One central point of Helvidius was that war had never been an executive power, and thus the grant of war power to Congress should not be construed strictly, as Hamilton argued. In making this argument, Madison, used the phrases "declare war" and "make war" interchangeably, and plainly intended, like Hamilton/Pacificus, to refer to the initiation of a state of war. See id. Madison added that because the President was the one who would "conduct" the war as a result of the commander-in-chief power, the President could not be a proper judge of whether " $a$ war ought to be commenced." Id at 618.

114 Elsewhere I have argued that the broader view of executive power expressed in Madison's Helvidius is inconsistent with the ordinary meaning of the Constitution's text, and therefore should be disregarded. See Prakash and Ramsey, 111 Yale L J at 334-39 (cited in note 14). 


\section{MiscELlanEOUS MATtERS}

The foregoing discussion explains why I find Professor Yoo's critique of TWP unconvincing. His comments contain a few additional mischaracterizations which, while not affecting the central issues of our debate, nonetheless call for some response.

First, Professor Yoo misstates the ultimate conclusions of TWP. In his view, $T W P$ simply mirrors the views of pro-Congress scholars, and has only "added an extra twist in the road" to the same destination. "This is wrong on several counts. First, the supposed "extra twist" $T W P$ adds is the link between the text of the Constitution and the interpretation that ratification and post-ratification commentary laid upon it. This has been an important weakness in past accounts of congressional war power, for which they have been roundly criticized by advocates of presidential war powers such as Professor Yoo. ${ }^{116}$ More importantly, TWP does not reach the same conclusions as all proCongress scholars. The conclusions may look the same from Professor Yoo's vantage point, but I anticipate some strong objections from the congressional side as well. A careful read of TWP shows that it does not go so far in establishing a congressional monopoly over war power as many would like. ${ }^{17}$ In fact, the entire point of the last Part of the Article (which Professor Yoo does not discuss) is that the President retains substantial independent power in threatening and using military force. ${ }^{118}$

Relatedly, TWP addresses only the original understanding of the Constitution. Professor Yoo's Response includes observations about

115 Yoo, 69 U Chi L Rev at 1641 (cited in note 6).

116 See Yoo, 84 Cal L Rev 172-73 (cited in note 4).

117 For example, Professors Fisher and Glennon would apparently limit the President's war powers, at least as an original matter, to responding to sudden attacks. See Louis Fisher, Presidential War Power 185-90 (Kansas 1995) (disputing contemporary justifications of presidential dominance with respect to the war power); Michael J. Glennon, Constitutional Diplomacy 81 (Princeton 1990) ("There is no evidence that the Framers intended to confer upon the President any independent authority to commit the armed forces to combat, except in order to repel 'sudden attacks."').

118 See Ramsey, 69 U Chi L Rev at 1634-35 (cited in note 1). Because I have not studied the details of many modern uses of force, I would not wish to state conclusively which ones do and do not comport with the constitutional vision of war powers laid out in TWP. It seems clear, though, that Professor Yoo overstates the degree to which TWP would find these episodes constitutionally problematic. To take a few examples he cites, there is a reasonable case that the Vietnam War was constitutionally authorized by a congressional delegation of war power to the President, that President Bush's action against Panama was a permissible response to an opposing declaration, that President Clinton's action against Sudan and Afghanistan and President Reagan's attack on Libya were permissible responses to attacks on U.S. forces or citizens abroad, and that President Clinton's action in Bosnia, and perhaps President Reagan's action in Grenada, were permissible military actions not rising to the level of war. See id at 1628. Compare Yoo, $69 \mathrm{U}$ Chi L Rev at 1683 (cited in note 6) (claiming that under TWP's interpretation all of these would be "illegal"). 
modern implications, enlisting on his behalf post-World War II practice and the exigencies of today's war on terrorism. ${ }^{\text {119 }}$ But TWP does not say anything about how war powers should be applied today. It only investigates the best interpretation of war powers as the Constitution was written. I do not say that this is the only interesting question that can be asked about war powers; it is just the only one TWP addresses. ${ }^{200}$

Third, Professor Yoo makes the odd claim that TWP envisions greater judicial involvement in the exercise of war powers, in the sense of adjudicating when wars are and are not properly authorized. ${ }^{121}$ In fact, TWP makes absolutely no comment upon the so-called political question doctrine, by which modern courts have generally avoided deciding war powers controversies. ${ }^{122}$ The point of this doctrine is that, whether or not war initiation powers belong to the President, the courts will not, as a matter of the proper role of the judiciary, entertain lawsuits seeking to constrain the President's conduct of war. This conclusion about the role of the courts is not affected by the underlying allocation of war power. Professor Yoo has confused the merits of the question with its justiciability. TWP addresses only the former.

\section{CONCLUSION}

This Reply has argued that Professor Yoo, in his Response to Textualism and War Powers, never really grapples with its central points. The textual case against broad congressional war powers had previously rested in large part upon the proposition that the Constitution gives Congress only the power to declare war, and in the eighteenth century no one would have thought declaring war (in the sense of issuing a formal proclamation) would have been necessary to initiating war. At the same time, the affirmative textual case for presidential war powers had rested in large part upon the following propositions: (1) the executive power clause (and perhaps the commander-inchief clause) conveyed the foreign affairs and military power of the traditional chief executive in eighteenth-century political thought, which included war-initiation power; (2) the Declare War Clause did not qualify this grant, because the eighteenth century did not equate

119 See Yoo, 69 U Chi L Rev at 1642 (cited in note 6).

120 Professor Yoo has previously argued against interpretations that depend upon modern events and exigencies. See Yoo, $84 \mathrm{Cal} \mathrm{L}$ Rev at 172-73 (cited in note 4) ("As a written document, the Constitution's meaning does not change from the meaning it held for its drafters"; therefore it is appropriate to look for "indications of how Americans of the late eighteenth century understood the legal framework of war powers.").

121 See Yoo, $69 \mathrm{U}$ Chi L Rev at 1682 (cited in note 6) (claiming that I "must admit" that $T W P$ "contemplates a dramatic expansion of the judicial role").

122 See Baker v Carr, 369 US 186, 213-15 (1962) (suggesting that courts will defer to the political branches on many foreign affairs issues). 
formal declarations with beginning hostilities; and (3) the structural explanation for the Declare War Clause is that it gave Congress control over the legal aspect of war (rather than its political/military aspects) because in the eighteenth century a formal declaration was the means for invoking the laws of war under international law.

Textualism and War Powers challenges the second and third propositions in support of presidential war powers, and provides a response to the textual charge against Congress. It shows that "declaring" war in the eighteenth century could mean acts of hostility that initiated a state of war (in addition to meaning a formal proclamation); and it shows that the formal proclamation of war was not a prerequisite to a legal state of war in the eighteenth century, but rather was a useful but non-obligatory communicative and rhetorical device. As a result, it provides a textual basis for a moderate version of the case for Congress, and deprives the President's case of its strongest structural explanation of the Declare War Clause. Professor Yoo's comments range widely, but they fundamentally do not address either of these points. Many of Professor Yoo's specific objections are important, and this Reply has endeavored to give them the consideration and response they deserve, but the ultimate conclusion must be that he has done little to undermine TWP's core observations upon the textual aspects of the war powers debate. 